\title{
Larval and juvenile Pacific herring Clupea pallasii are not susceptible to infectious hematopoietic necrosis under laboratory conditions
}

\author{
Lucas M. Hart ${ }^{1, *}$, Garth S. Traxler ${ }^{2}$, Kyle A. Garver ${ }^{2}$, Jon Richard ${ }^{2}$, Jacob L. Gregg ${ }^{1}$, \\ Courtney A. Grady ${ }^{1}$, Gael Kurath ${ }^{3}$, Paul K. Hershberger ${ }^{1}$ \\ ${ }^{1}$ Marrowstone Marine Field Station, Western Fisheries Research Center (WFRC), US Geological Survey, Nordland, \\ Washington 98358, USA \\ ${ }^{2}$ Pacific Biological Station, Fisheries and Oceans Canada, Nanaimo, British Columbia V9T 6N7, Canada \\ ${ }^{3}$ WFRC, US Geological Survey, Seattle, Washington 98115, USA
}

\begin{abstract}
Infectious hematopoietic necrosis (IHN) leads to periodic epidemics among certain wild and farmed fish species of the Northeast (NE) Pacific. The source of the IHN virus (IHNV) that initiates these outbreaks remains unknown; however, a leading hypothesis involves viral persistence in marine host species such as Pacific herring Clupea pallasii. Under laboratory conditions we exposed specific pathogen-free (SPF) larval and juvenile Pacific herring to $10^{3}$ to $10^{4}$ plaque-forming units (pfu) of IHNV ml-1 by waterborne immersion. Cumulative mortalities among exposed groups were not significantly different from those of negative control groups. After waterborne exposure, IHNV was transiently recovered from the tissues of larvae but absent in tissues of juveniles. Additionally, no evidence of viral shedding was detected in the tank water containing exposed juveniles. After intraperitoneal (IP) injection of IHNV in juvenile herring with $10^{3} \mathrm{pfu}$, IHNV was recovered from the tissues of sub-sampled individuals for only the first $5 \mathrm{~d}$ post-exposure. The lack of susceptibility to overt disease and transient levels of IHNV in the tissues of exposed fish indicate that Pacific herring do not likely serve a major epizootiological role in perpetuation of IHNV among free-ranging sockeye salmon Oncorhynchus nerka and farmed Atlantic salmon Salmo salar in the NE Pacific.
\end{abstract}

KEY WORDS: IHN · Infectious hematopoietic necrosis · Pacific herring $\cdot$ Clupea pallasii Resale or republication not permitted without written consent of the publisher

\section{INTRODUCTION}

Infectious hematopoietic necrosis virus (IHNV), a rhabdovirus that causes acute disease (IHN) in salmonids, was first described in hatchery-reared sockeye salmon Oncorhynchus nerka in 1953 (Rucker et al. 1953) and identified in 1969 (Amend et al. 1969). Since these initial reports, surveillance and monitoring programs have established IHNV as being enzootic to the Pacific Northwest of North America; the virus is now found throughout Europe and Asia presumably as a result of transferring infected eggs and fish (Kuzmin et al. 2009).

Infectious hematopoietic necrosis epizootics are known to occur in wild and cultured salmon and trout species (Bootland \& Leong 1999), which in some instances can result in severe mortality. Epizootics of IHNV in feral or wild fish have occurred in sockeye salmon fry in tributaries of the Fraser River, British Columbia, Canada (Williams \& Amend 1976, Traxler \& Rankin 1989), kokanee Oncorhynchus nerka yearlings in Lake Billy Chinook, Oregon, USA (Anderson et al. 2000), an enhanced population of sockeye salmon smolts at Hidden Creek, Alaska, USA (Burke \& Grischkowsky 1984) and in adult kokanee salmon at Lake Cowichan, British Columbia (Traxler 1986). Among cultured fish, epizootics occur periodically in Pacific salmon hatcheries and spawning channels along the west coast of North America (Traxler \& Rankin 1989), rainbow trout Oncorhynchus mykiss culture facilities in Hagerman Valley, Idaho, USA (Busch 1983) and in sea-pen reared Atlantic salmon Salmo 
salar in the coastal waters of British Columbia (StHilaire et al. 2002, Saksida 2006).

Despite the virulence and extensive distribution of IHNV, the epizootiology of the virus in salmonids is not well understood. The predominant occurrence of virus infection and disease outbreaks in salmonids in freshwater suggests that the fish are exposed to virus from freshwater reservoirs; however, the role of a marine host or reservoir can not be discounted in the perpetuation of IHNV. The occurrence of IHNV epizootics in farmed Atlantic salmon suggest the initial exposure to IHNV likely occurred in seawater (Saksida 2006), though the exact reservoir or source of virus in the marine environment remains unclear.

Epidemiological examination of IHNV epizootics in farmed Atlantic salmon has been suggestive of sockeye salmon and Pacific herring Clupea pallasii providing the initial source of IHNV transmission (Saksida 2006). The virus has been detected in sockeye salmon at the end of their marine phase (Traxler et al. 1997), and laboratory trials have demonstrated that Atlantic salmon develop IHN disease when cohabitated with IHNV-infected sockeye salmon (Traxler et al. 1993). During a health survey of marine fish, IHNV was detected in 1 out of 289 wild Pacific herring in the marine waters of British Columbia (Kent et al. 1998). However, there is only limited information regarding the susceptibility of Pacific herring to IHNV infection and disease.

This study was designed to investigate the ability of Pacific herring, a primary forage species throughout the northeast Pacific, to serve as a natural marine host of IHNV. Specifically, laboratory studies were undertaken to determine whether larval and juvenile Pacific herring are susceptible to IHN disease and viral infection. Further, we conducted experiments in juvenile herring to determine which tissue types may be infected with IHNV and whether viral shedding occurs after exposure.

\section{MATERIALS AND METHODS}

Fish. As a source of herring for all experiments, naturally spawned Pacific herring eggs attached to submerged macrophytes were collected from locations throughout Puget Sound, Washington, USA. Eggs were hatched and larvae were reared at the US Geological Survey Marrowstone Marine Field Station under specific pathogen-free (SPF) conditions (Hershberger et al. 2010a).

Virus amplification and enumeration. The isolates of IHNV used in this study, denoted $02-040$ or 93-057, originated from a clinical outbreak of IHNV on an Atlantic salmon net pen farm in British Columbia,
Canada. Phylogenetically, the virus groups into the enzootic U-genogroup (G. Kurath unpubl. data) as defined by partial G gene sequence typing (Kurath et al. 2003). For transmission experiments, virus was propagated at a low multiplicity of infection (MOI) ( 0.001) on epithelioma papulosum cyprini cells (EPC) (Fijan et al. 1983, Winton et al. 2010). Harvested virus was stored at $-80^{\circ} \mathrm{C}$. IHNV titers in thawed virus stock aliquots, and in tissue and water samples from experiments described below, were enumerated by plaque assay (Hershberger et al. 2010b) on monolayers of EPC cells (Fijan et al. 1983). Minimum detection thresholds were $400 \mathrm{pfu} \mathrm{g}^{-1}$ (tissue) and 20 plaque-forming units (pfu) $\mathrm{ml}^{-1}$ (water).

Viral immersion challenges. To determine whether larval and juvenile Pacific herring were susceptible to IHN disease after waterborne exposure, aliquots of IHNV 93-057 isolate were added to 5 replicate 351 aquaria containing age $9 \mathrm{~d}$ (332 to 537 herring tank $^{-1}$ ), $57 \mathrm{~d}$ ( 97 to 140 herring tank $^{-1}$ ), and $63 \mathrm{~d}$ (8 to 15 herring tank $\left.^{-1}\right)$ SPF larvae and 2701 tanks containing $1+$ yr (12 to 13 mo old) (33 to 36 herring tank ${ }^{-1}$ ) SPF juveniles. Negative control groups for each age class ( $\mathrm{n}=5$ tanks age $^{-1}$ ) were exposed to Eagle's minimum essential medium (MEM) in lieu of virus. Herring in all treatment tanks were challenged with IHNV by static immersion in $10^{3} \mathrm{pfu} \mathrm{ml}^{-1}$ for $1 \mathrm{~h}$ in ambient seawater (8.7 to $11.6^{\circ} \mathrm{C}$ ). This exposure level is consistent with water titers thought to occur under natural conditions (Mulcahy et al. 1983, Bootland \& Leong 1999). Viral exposure titer was enumerated by plaque assay at the end of the $1 \mathrm{~h}$ challenge (Table 1 ). Water supply to all tanks was resumed after the $1 \mathrm{~h}$ exposure and the experiments continued for $21 \mathrm{~d}$. Mortalities were collected daily throughout the experiment and surviving fish on Day 21 were euthanized with an overdose of buffered tricaine methanesulfonate (MS-222). Negative controls were periodically sampled throughout the experiment. Prevalence of IHNV infection among all sampled herring was determined by plaque assay of whole-body tissue homogenates. Cumulative mortality $( \pm S D)$ for each treatment group was calculated as the mean of arc sine-transformed proportions among the replicates; means were then reported as percentages corresponding to the back-transformed proportions. Cumulative percent mortalities between exposed and control treatments were compared at the end of the experiment (21 d post-exposure) using a 1-tailed Student's $t$-test; comparisons were considered significant if $p<0.05$.

Viral shedding. To determine whether viral shedding occurred after exposure of Pacific herring to IHNV, age $1+y r$ SPF juveniles $(n=76)$ in a single $270 \mathrm{l}$ tank were exposed to $1.5 \times 10^{4} \mathrm{pfu}$ virus $\mathrm{ml}^{-1}$ (isolate 02-040) by immersion challenge as described above; a negative control group consisted of an analogous tank 
Table 1. Clupea pallasii. Mean water titer at time of initial exposure and number of fish per tank for Pacific herring treated with infectious hematopietic necrosis virus (IHNV) or Eagle's minimum essential medium (MEM, negative control) in herring susceptibility experiments, each treatment with 5 replicate tanks. pfu: plaque-forming units

\begin{tabular}{|c|c|c|c|c|c|c|c|c|}
\hline & \multicolumn{2}{|c|}{9 d larvae } & \multicolumn{2}{|c|}{57 d larvae } & \multicolumn{2}{|c|}{63 d larvae } & \multicolumn{2}{|c|}{ 1+ yr juveniles } \\
\hline & IHNV & Control & IHNV & Control & IHNV & Control & IHNV & Control \\
\hline Water titer pfu $\mathrm{ml}^{-1}$ & $2.4 \times 10^{3}$ & 0 & $4.0 \times 10^{3}$ & 0 & $3.5 \times 10^{3}$ & 0 & $2.3 \times 10^{3}$ & 0 \\
\hline No. $\operatorname{tank}^{-1}$ & $332-537$ & $290-506$ & $97-140$ & $76-124$ & $8-15$ & $3-9$ & $33-36$ & $32-35$ \\
\hline
\end{tabular}

of herring $(\mathrm{n}=27)$ that were exposed to MEM in lieu of virus. Viral shedding was monitored by collecting water samples from both tanks on Days 0, 5, 10, 15, and 20 post-exposure; the supply water to the tanks was discontinued for $1 \mathrm{~h}$ prior to sampling in an effort to concentrate shed virus. Water samples consisted of $1 \mathrm{ml}$ of static tank water that was diluted 1:1 in MEM supplemented with $10 \%$ fetal bovine serum, 100 IU $\mathrm{ml}^{-1}$ penicillin, $100 \mu \mathrm{g} \mathrm{ml}^{-1}$ streptomycin, $100 \mu \mathrm{g} \mathrm{ml}^{-1}$ gentamycin and $2.5 \mathrm{\mu g} \mathrm{ml}^{-1}$ amphotericin B. Supply water to the tanks was then resumed and water samples were processed by plaque assay. To determine whether the exposed herring replicated IHNV in the absence of mortality, sub-samples of fish were collected from the exposed and control ( $\mathrm{n}=15$ herring $\operatorname{tank}^{-1} \mathrm{~d}^{-1}$ and 5 herring tank $\mathrm{k}^{-1} \mathrm{~d}^{-1}$, respectively) treatments on Days 0, 5, 10, 15, and 20 post-exposure. Presence of IHNV in all mortalities and sub-sampled fish was determined by separate plaque assay of brain, skin, mucus, and pools of kidney-spleen tissues.

Viral injection challenges. To determine whether juvenile Pacific herring are able to replicate IHNV after injection challenge, age 1+ yr SPF Pacific herring ( $\mathrm{n}=25$ ) were exposed by intraperitoneal injection of $100 \mu \mathrm{l}$ aliquots containing $5.8 \times 10^{3} \mathrm{pfu}$ of virus (isolate 02-040); negative controls $(\mathrm{n}=15$ ) were injected with $100 \mu \mathrm{l}$ of phosphate-buffered saline (PBS). Exposed and control groups were maintained in separate $270 \mathrm{l}$ tanks supplied with flow-through, processed seawater. Sub-samples of fish were collected from the exposed and control groups on Days 3, 5, 12 and 21 post-exposure and euthanized with an overdose of buffered MS222. IHNV presence in all sampled fish was determined by plaque assay of flank (muscle with skin intact) and kidney-spleen pools from individual fish.

Positive control. To assure the virulence of our IHNV strain, we intraperitoneally injected 10 Atlantic salmon with $5 \times 10^{3}$ pfu ml ${ }^{-1}$ IHNV strain 02-040 at ambient seawater temperature. Mortality was monitored for $34 \mathrm{~d}$ and presence of IHNV was determined by plaque assay in mortalities and survivors. Six of the 10 injected salmon reached mortality by Day 13, 5 of which tested positive for IHNV. One of the 4 surviving salmon tested positive for IHNV.

\section{RESULTS}

Among larval and juvenile herring immersed in IHNV, cumulative percent mortality was not significantly different (Student's $t$-test, $\mathrm{p}>0.05$ ) from controls within any of the age groups (Fig. 1). Among groups of larvae ( $9 \mathrm{~d}, 56 \mathrm{~d}$, and $63 \mathrm{~d}$ ages), cumulative mortality increased steadily in both treatment and control groups during the $21 \mathrm{~d}$ post-exposure period (Fig. 1) and was characteristic of handling and transfer mortality that typically occurs during this fragile life history stage (Hershberger et al. 2007). Juvenile herring (1+ yr age groups) had no incidental mortality in control groups and very low mortality in virus-exposed groups.

For all age groups, there was no virus detected in fish that died before 5 to $6 \mathrm{~d}$ post-exposure (Table 2). After this early period, virus was recovered from all larval groups, but the duration of persistence of IHNV infections was inversely related to the age of exposed Pacific herring. Among the youngest groups of exposed Pacific herring (9 d larvae), IHNV was recovered from a proportion (range: 20 to $70 \%$ ) of the mortality pools on nearly every day from Day 5 through the end of the $21 \mathrm{~d}$ study period, and from 4 of 20 pools of survivors occurring $21 \mathrm{~d}$ post-exposure (Table 2). The persistence of IHNV infections was shorter in older larvae, with IHNV-positive mortality occurring only 5 to $11 \mathrm{~d}$ post-exposure among $57 \mathrm{~d}$ larvae and only at $6 \mathrm{~d}$ post-exposure among 63 d larvae; IHNV was not detected in any survivors among the 57 or $63 \mathrm{~d}$ larval cohort (Table 2). Further, IHNV was not recovered from any age 1+ yr juvenile herring after waterborne exposure. All negative controls were free of virus (Table 2).

In a separate experiment, shed IHNV was not detected from post-exposure water samples in any of the tanks containing age 1+ yr SPF herring that were exposed to IHNV by waterborne immersion. As before, significant mortality did not occur after exposure (control mortalities $=1 / 27$; treatment mortalities $=5 / 76$ ). Further, IHNV was not recovered from the tissues of any exposed herring (mortalities; subsampled survivors ( $\mathrm{n}=10$ to $15 \mathrm{~d}^{-1}$ ) from Days 0,5 , 10 , 15 , or 20 ). 

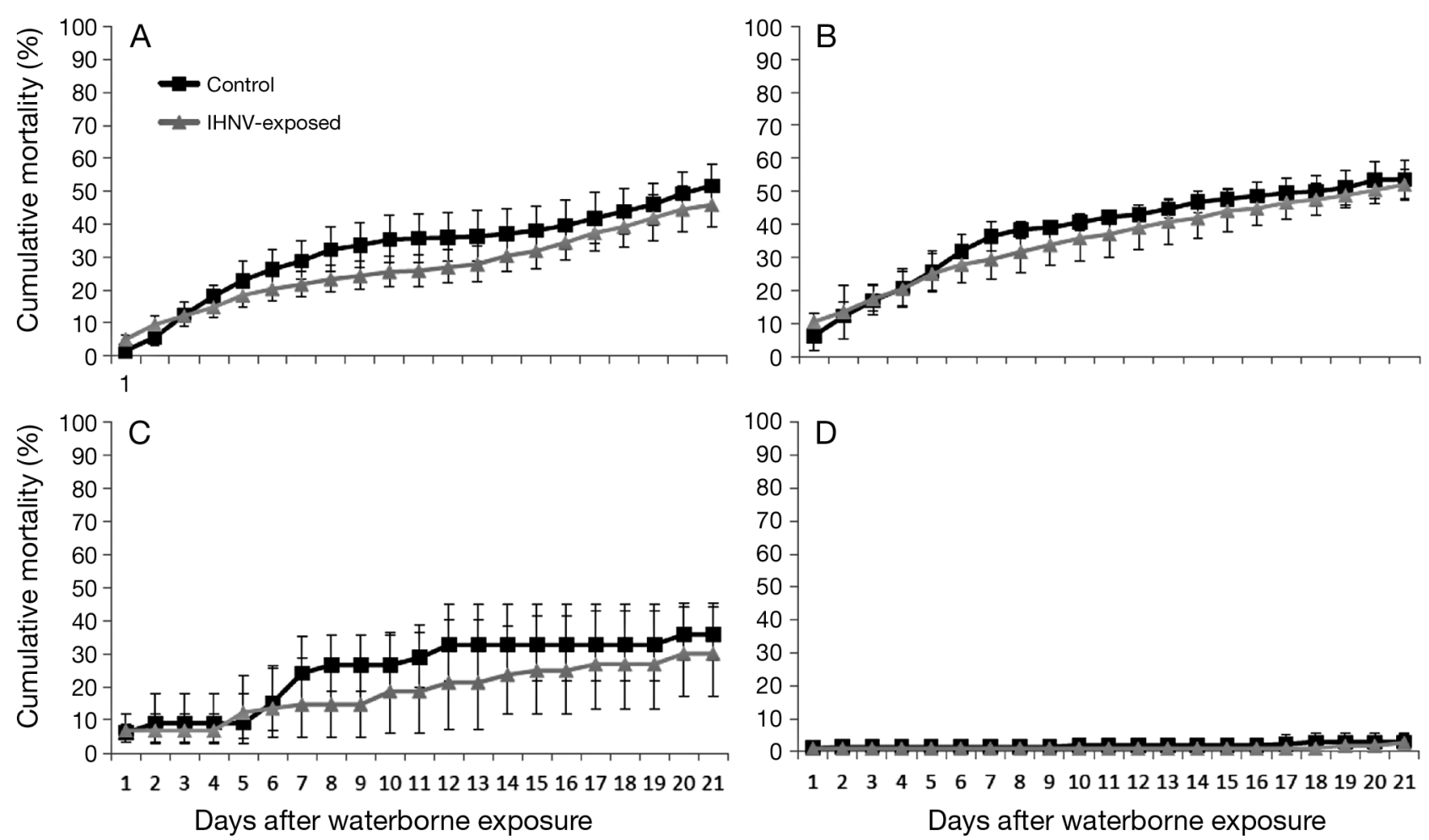

Fig. 1. Clupea pallasii. Susceptibility of Pacific herring to infectious hematopietic necrosis virus (IHNV). (A) Age 9 d larvae, (B) age $56 \mathrm{~d}$ larvae, (C) age $63 \mathrm{~d}$ larvae, (D) age 1+ yr juveniles. Percent cumulative mortality represents the back-transformed mean of the transformed data from the 5 replicates for each group. Error bars are SD

Intraperitoneal injection of $1+$ yr age juvenile Pacific herring with aliquots of IHNV did not result in any IHNV-positive host mortalities among those randomly tested; however, virus was transiently recovered from tissues of live sub-samples. Among sub-sampled live herring, the prevalence of infection decreased from $80 \%(4 / 5)$, to $60 \%(3 / 5)$, and then $0 \%(0 / 5)$ after 3, 5 , and $12 \mathrm{~d}$ post-exposure (Table 3 ). IHNV was recovered from both kidney-spleen pools and flank samples at titers ranging from $10^{2}$ to $>10^{7} \mathrm{pfu} \mathrm{g}^{-1}$ (tissue); geometric mean tissue titers from all positive fish were $3.8 \times$ $10^{4} \mathrm{pfu} \mathrm{g}^{-1}$ for kidney-spleen pools and $3.2 \times 10^{4} \mathrm{pfu}$ $\mathrm{g}^{-1}$ for flank samples (Table 3 ).

\section{DISCUSSION}

The lack of susceptibility to overt disease and transient recovery of virus from the tissues of exposed survivors indicate that Pacific herring do not likely serve a major epizootiological role in perpetuation of IHNV among free-ranging sockeye salmon and farmed Atlantic salmon in the northeast Pacific. Larval and juvenile herring exposed to maximal levels of virus found to occur under natural conditions $\left(10^{3} \mathrm{pfu} \mathrm{m}^{-1}\right)$ (Mulcahy et al. 1983, Bootland \& Leong 1999) were refractory to
IHN disease. The presence of virus in $9 \mathrm{~d}$ old survivors and absence of virus in older age cohorts suggests that the developmental stage at which exposure occurs is a determinant of infectivity in Pacific herring.

The isolation of IHNV from a single wild Pacific herring along the coast of British Columbia (Kent et al. 1998) is an interesting observation and an unexpected finding when considering the results of our controlled studies. Higher localized IHNV exposure titers or extended waterborne exposure times in excess of $1 \mathrm{~h}$ may lead to rare infection in wild Pacific herring. Alternatively, IHNV carrier states have been documented in adult rainbow trout exposed to the virus at young ages (Amend 1975). Therefore, under different virus exposure conditions than those utilized in the present study, it is possible that an infected larval herring may act as an IHNV carrier throughout its life history. Unidentified marine carriers may also contribute to infections in free-ranging Pacific herring; this has been demonstrated in freshwater systems (Mulcahy et al. 1990).

Although IHNV was not virulent to any life stage of Pacific herring examined, the ability of the virus to replicate in the tissues of exposed herring was inversely related to the age of the host, and the virus persisted in the youngest larvae for the longest durations. The skin of larval herring consists of only 2 lay- 
Table 2. Clupea pallasii. Infectious hematopietic necrosis virus (IHNV) in the tissues (whole bodies) of larval and juvenile Pacific herring that were exposed to IHNV or Eagle's minimum essential medium (MEM, negative control) by immersion challenge. Incl.: inclusive; blank cells: no data

\begin{tabular}{|c|c|c|c|c|c|c|c|c|c|c|c|c|}
\hline \multirow{2}{*}{$\begin{array}{l}\text { Days after } \\
\text { waterborne } \\
\text { exposure }\end{array}$} & \multirow{2}{*}{\multicolumn{2}{|c|}{$\begin{array}{cc} & \text { d larvae } \\
\text { Incl. no. } & \text { Pooled } \\
\text { of fish } & \text { samples }\end{array}$}} & \multirow{2}{*}{$\begin{array}{c}\overline{\text { IHNV }} \\
\text { positive }\end{array}$} & \multicolumn{3}{|c|}{$-57 \mathrm{~d}$ larvae } & \multicolumn{3}{|c|}{$-63 \mathrm{~d}$ larvae } & \multicolumn{3}{|c|}{$-1+$ yr juveniles } \\
\hline & & & & $\begin{array}{l}\text { Incl. no. } \\
\text { of fish }\end{array}$ & $\begin{array}{c}\text { Pooled } \\
\text { samples }\end{array}$ & $\begin{array}{c}\text { IHNV } \\
\text { positive }\end{array}$ & $\begin{array}{l}\text { Incl. no. } \\
\text { of fish }\end{array}$ & $\begin{array}{c}\text { Pooled } \\
\text { samples }\end{array}$ & $\begin{array}{l}\text { IHNV } \\
\text { positive }\end{array}$ & $\begin{array}{l}\text { Incl. no. } \\
\text { of fish }\end{array}$ & $\begin{array}{c}\text { Pooled } \\
\text { samples }\end{array}$ & $\begin{array}{l}\text { IHNV } \\
\text { positive }\end{array}$ \\
\hline \multicolumn{13}{|c|}{ IHNV-exposed mortalities } \\
\hline 1 & 112 & 5 & 0 & 62 & 60 & 0 & 4 & 4 & 0 & & & \\
\hline 2 & 106 & 6 & 0 & 18 & 18 & 0 & & & & & & \\
\hline 3 & 59 & 5 & 0 & 23 & 23 & 0 & & & & & & \\
\hline 4 & 61 & 5 & 0 & 18 & 18 & 0 & & & & & & \\
\hline 5 & 74 & 5 & 1 & 28 & 28 & 4 & 3 & 3 & 0 & & & \\
\hline 6 & 41 & 5 & 3 & 17 & 16 & 3 & 1 & 1 & 1 & & & \\
\hline 7 & 33 & 5 & 2 & 9 & 9 & 0 & 1 & 1 & 0 & & & \\
\hline 8 & 34 & 5 & 1 & 14 & 12 & 7 & & & & & & \\
\hline 9 & 25 & 5 & 1 & 12 & 12 & 0 & & & & & & \\
\hline 10 & 30 & 5 & 3 & 12 & 11 & 0 & 2 & 2 & 0 & & & \\
\hline 11 & 8 & 8 & 2 & 7 & 7 & 7 & & & & & & \\
\hline 12 & 25 & 5 & 2 & 12 & 12 & 0 & 2 & 2 & 0 & & & \\
\hline 13 & 20 & 7 & 5 & 10 & 10 & 0 & & & & & & \\
\hline 14 & 58 & 5 & 2 & 5 & 5 & 0 & 1 & 1 & 0 & & & \\
\hline 15 & 34 & 4 & 0 & 13 & 13 & 0 & 1 & 1 & 0 & & & \\
\hline 16 & 59 & 5 & 2 & 5 & 5 & 0 & & & & & & \\
\hline 17 & 62 & 5 & 2 & 11 & 11 & 0 & 1 & 1 & 0 & & & \\
\hline 18 & 42 & 5 & 1 & 6 & 6 & 0 & & & & & & \\
\hline \multicolumn{13}{|l|}{19} \\
\hline 20 & 55 & 5 & 2 & 10 & 10 & 0 & 2 & 2 & 0 & & & \\
\hline 21 & 31 & 5 & 1 & 9 & 9 & 0 & & & & 2 & 2 & 0 \\
\hline \multicolumn{13}{|c|}{ IHNV-exposed survivors } \\
\hline 21 & 560 & 20 & 4 & 45 & 45 & 0 & 22 & 22 & 0 & 172 & 40 & 0 \\
\hline \multicolumn{13}{|c|}{ Live sub-sampled negative controls } \\
\hline 2 & 87 & 7 & 0 & 33 & 13 & 0 & 1 & 1 & 0 & 1 & 1 & 0 \\
\hline 15 & 23 & 5 & 0 & 5 & 5 & 0 & & & & & & \\
\hline 18 & 46 & 5 & 0 & 2 & 2 & 0 & & & & & & \\
\hline 20 & 69 & 7 & 0 & 12 & 12 & 0 & 1 & 1 & 0 & 1 & 1 & 0 \\
\hline
\end{tabular}

Table 3. Clupea pallasii. Infectious hematopoietic necrosis virus (IHNV) titer in the tissues (kidney-spleen and flank) of age 1+ yr juvenile herring injected with IHNV or phosphate-buffered saline (PBS, negative control) and sub-sampled on 4 separate days post-injection. pfu: plaque-forming units

\begin{tabular}{|c|c|c|c|c|}
\hline $\begin{array}{l}\text { Day } \\
\text { post-injection }\end{array}$ & $\begin{array}{l}\text { No. of fish } \\
\text { tested }\end{array}$ & $\begin{array}{l}\text { No. of fish } \\
\text { IHNV } \\
\text { positive }\end{array}$ & $\begin{array}{l}\text { IHNV titer in } \\
\text { kidney-spleen } \\
\text { pools (pfu g }{ }^{-1} \text { ) }\end{array}$ & $\begin{array}{l}\text { IHNV titer in } \\
\text { flank (pfu g }{ }^{-1} \text { ) }\end{array}$ \\
\hline \multicolumn{5}{|l|}{ IHNV injected } \\
\hline 3 & 5 & 4 & $\begin{array}{l}8.8 \times 10^{4} \\
4 \times 10^{7} \\
4 \times 10^{2}{ }^{3} \\
2.4 \times 10^{3}\end{array}$ & $\begin{array}{c}4.8 \times 10_{5}^{3} \\
1.5 \times 10^{2} \\
0 \\
0\end{array}$ \\
\hline 5 & 5 & 3 & $\begin{array}{c}0 \\
1 \times 10^{5} \\
0\end{array}$ & $\begin{array}{l}3.7 \times 10_{4}^{4} \\
8.0 \times 10_{4} \\
1.6 \times 10\end{array}$ \\
\hline 12 & 5 & 0 & 0 & 0 \\
\hline 21 & 1 & 0 & 0 & 0 \\
\hline \multicolumn{5}{|c|}{ Negative controls } \\
\hline 3 & 3 & 0 & 0 & 0 \\
\hline 5 & 5 & 0 & 0 & 0 \\
\hline 12 & 3 & 0 & 0 & 0 \\
\hline 21 & 2 & 0 & 0 & 0 \\
\hline
\end{tabular}

ers of epithelial cells and becomes progressively more complex over the course of development (Hickey 1982). The ability of IHNV to replicate more effectively during earlier developmental stages in Pacific herring may suggest that the virus has a tropic affinity for epithelium. Additionally, small lymphocyte development, and thus primary immunological defense mechanisms, do not begin developing until several weeks post-hatch in teleost fish (Chantanachookhin et al. 1991). Therefore, non-specific mechanisms, such as mucus secretion, are suggested to be the major defense against infections in larval fish (Ottesen \& Olafsen 2000), leaving them vulnerable to viral infection. After metamorphosis to juveniles, non-specific immunity remains the first line of defense 
against infection (Tort et al. 2003). However, even when these first lines of defense were circumvented by direct injection of the virus into the body cavity of naïve herring, herring remained refractory to the disease and viral replication was transient.

Acknowledgements. Funding was provided by the Exxon Valdez Oil Spill Trustee Council, Project \# 070819, Fisheries and Oceans Canada, and US Geological Survey Fisheries and Aquatic Resources Program. The use of trade, firm, or corporation names in this publication is for the information and convenience of the reader. Such use does not constitute an official endorsement or approval by the US Department of Interior or the US Geological Survey of any product or service to the exclusion of others that may be suitable.

\section{LITERATURE CITED}

Amend DF (1975) Detection and transmission of infectious hematopoietic necrosis virus in rainbow trout. J Wildl Dis 11:471-478

Amend D, Yasutake W, Mead R (1969) A hematopoietic virus disease of rainbow trout and sockeye salmon. Trans Am Fish Soc 98:796-804

Anderson E, Engelking H, Emmenegger E, Kurath G (2000) Molecular epidemiology reveals emergence of a virulent IHN virus strain in wild salmon and transmission to hatchery fish. J Aquat Anim Health 12:85-99

Bootland L, Leong J (1999) Infectious hematopoietic necrosis virus. In: Bruno DW, Woo PTK (eds) Fish diseases and disorders, Vol 3. CAB International, Wallingford, p 57-121

Burke J, Grischkowsky R (1984) An epizootic caused by infectious haematopoietic necrosis virus in an enhanced population of sockeye salmon, Oncorhynchus nerka (Walbaum), smolts at Hidden Creek, Alaska. J Fish Dis 7: 421-429

Busch R (1983) Viral disease considerations in the commercial trout industry in Idaho. In: Leong J, Barila T (eds) Workshop on viral diseases of salmonid fishes in the Columbia River Basin. Spec Publ Bonneville Power Admin, Portland, OR, p 84-100

> Chantanachookhin C, Seikai T, Tanaka M (1991) Comparative study of the ontogeny of the lymphoid organs in 3 species of marine fish. Aquaculture 99:143-150

Fijan N, Sulimanovic D, Bearzotti M, Muzinic D and others (1983) Some properties of the epithelioma papulosum cyprini (EPC) cell line from carp Cyprinus carpio. Elsevier, Paris, p 207-220

> Hershberger PK, Gregg J, Pacheco C, Winton J, Richard J, Traxler G (2007) Larval Pacific herring, Clupea pallasii (Valenciennes), are highly susceptible to viral haemorrhagic septicaemia and survivors are partially protected after their metamorphosis to juveniles. J Fish Dis 30: $445-458$

> Hershberger PK, Gregg J, Grady C, Collins R, Winton J (2010a) Susceptibility of three stocks of Pacific herring to viral hemorrhagic septicemia. J Aquat Anim Health 22:1-7

Hershberger PK, Gregg J, Grady C, Collins R, Winton J (2010b) Kinetics of viral shedding provide insights into the epidemiology of viral hemorrhagic septicemia in Pacific herring. Mar Ecol Prog Ser 400:187-193
Hickey G (1982) Wound healing in fish larvae. J Exp Mar Biol Ecol 57:149-168

Kent M, Traxler G, Kieser D, Richard J and others (1998) Survey of salmonid pathogens in ocean-caught fishes in British Columbia, Canada. J Aquat Anim Health 10: 211-219

> Kurath G, Garver K, Troyer R, Emmenegger E, Einer-Jensen K, Anderson E (2003) Phylogeography of infectious haematopoietic necrosis virus in North America. J Gen Virol 84:803-814

- Kuzmin IV, Novella I, Dietzgen R, Padhi A, Rupprecht C (2009) The rhabdoviruses: biodiversity, phylogenetics, and evolution. Infect Genet Evol 9:541-553

> Mulcahy D, Pascho R, Jenes C (1983) Detection of infectious haematopoietic necrosis virus in river water and demonstration of waterborne transmission. J Fish Dis 6: $321-330$

> Mulcahy D, Klaybor D, Batts W (1990) Isolation of infectious hematopoietic necrosis virus from a leech (Piscicola salmositica) and a copepod (Salmincola sp.), ectoparasites of sockeye salmon Oncorhynchus nerka. Dis Aquat Org 8: 29-34

> Ottesen O, Olafsen J (2000) Effects on survival and mucous cell proliferation of Atlantic halibut, Hippoglossus hippoglossus L., larvae following microflora manipulation. Aquaculture 187:225-238

Rucker RR, Whipple WJ, Parvin JR, Evans CA (1953) A contagious disease of salmon possibly of virus origin. US Fish Wildl Serv Fish Bull 54:35-46

> Saksida SM (2006) Infectious haematopoietic necrosis epidemic (2001 to 2003) in farmed Atlantic salmon Salmo salar in British Columbia. Dis Aquat Org 72:213-223

St-Hilaire S, Ribble C, Stephen C, Anderson E, Kurath G, Kent M (2002) Epidemiological investigation of infectious hematopoietic necrosis virus in salt water net-pen reared Atlantic salmon in British Columbia, Canada. Aquaculture 212:49-67

Tort L, Balasch JC, Mackenzie S (2003) Fish immune system. A crossroads between innate and adaptive responses. Inmunología 22:277-286

> Traxler GS (1986) An epizootic of infectious hematopoietic necrosis virus in 2-year-old kokanee, Oncorhynchus nerka (Walbaum), at Lake Cowichan. British Columbia. J Fish Dis 9:545-549

> Traxler GS, Rankin J (1989) An infectious hematopoietic necrosis epizootic in sockeye salmon Oncorhynchus nerka in Weaver Creek spawning channel, Fraser River system, B.C., Canada. Dis Aquat Org 6:221-226

Traxler GS, Roome J, Kent M (1993) Transmission of infectious hematopoietic necrosis virus in seawater. Dis Aquat Org 16:111-114

Traxler GS, Roome J, Lauda K, LaPatra S (1997) Appearance of infectious hematopoietic necrosis virus (IHNV) and neutralizing antibodies in sockeye salmon Onchorynchus nerka during their migration and maturation period. Dis Aquat Org 28:31-38

Williams I, Amend D (1976) A natural epizootic of infectious hematopoietic necrosis in fry of sockeye salmon (Oncorhynchus nerka) at Chilko Lake, British Columbia. J Fish Res Board Can 33:1564-1567

Winton J, Batts W, Dekinkelin P, Leberre M, Bremont M, Fijan $N$ (2010) Current lineages of the epithelioma papulosum cyprini (EPC) cell line are contaminated with fathead minnow, Pimephales promelas, cells. J Fish Dis 33:701-704

Submitted: July 20, 2010; Accepted: September 30, 2010

Proofs received from author(s): December 23, 2010 